https://ejournal.uniska-kediri.ac.id/index.php/PROFICIENCY

\title{
THE CORRELATION BETWEEN GRAMMAR AND VOCABULARY MASTERY TOWARD SPEAKING SKILL AMONG THE SEVENTH GRADE STUDENTS OF MTSN 1 KEDIRI
}

\author{
By: Galih Putri Kemala Sari
}

\begin{abstract}
This research is aimed to know whether there is significant correlation between grammar and vocabulary mastery toward speaking skill among the seventh grade students of MTsN 1 Kediri. The design of this research was descriptive quantitative. The sample was 194 students. . The research instruments in this research were tests and questionnaire. The result was there is significant correlation between grammar and vocabulary mastery toward speaking skill among the seventh grade students of MTsN 1 Kediri. The value of correlation between $\mathrm{X} 1$ and $\mathrm{Y}$ is 0,46 , then for correlation between $\mathrm{X} 2$ and $\mathrm{Y}$ is 0,234 . It is recommended for the teachers to pay attention to the students' speaking skill.
\end{abstract}

$\overline{\text { Key words: grammar mastery, speaking skill, vocabulary mastery }}$

\section{INTRODUCTION}

In modern era English is a crucial skill to have. There are many students from another countries around the world learn English. Since English becomes international language, we should know and understand English in order to not miss out information. Mastering this language is not easy. There are some skills, such as speaking, listening, writing and reading. From some skills, the most used in daily is speaking because it is used to communicate. Shumin (2002, 204205) states that speaking a language involves more than knowing the linguistic components of the message and developing language skills; therefore, it needs more than grammatical comprehension and vocabulary memorization.

Mastering grammar is very important part in speaking. It is like the soul of speaking as if witout grammar, the speaking is as body without a soul,so it will walk everywhere. Grammar is thought to provide the basis for a set of language skills. In the context of speaking, grammar lets learners put their ideas into coherence sentence, so they can communicate their speaking well. Batko (2004:22) says that "grammar is needed in spoken language in order to arrange the correct sentence."

To get good speaking, it is not enough only master in grammar but also the vocabulary. Learning vocabulary is the most important part in mastering foreign language such as English as it is the fundamental form in expessing an idea or opinion in speaking. It is impossible that someone can understand the maning of what he reads or hears without knowing the vocabularies. Cameron 
https://ejournal.uniska-kediri.ac.id/index.php/PROFICIENCY

(2001) states that building up a useful vocabulary is central to the learning of a foreign language at primary level.

In Indonesia, English has been taught as one of subject in the formal school since 1945 after Indonesian independence. English is one of the important lesson in junior high scholl, senior high school and university. This research took place in MTsN 1 Kediri because it is one of good junior high school in Kediri. MTsN 1 Kediri has good learning accommodation, complete facilities, good school programs and school achievement in local, regional and national level. Based on the explanation above, the researcher would like to have the research by the title "The Correlation between Grammar and Vocabulary Mastery toward Speaking Skill among the Seventh grade Students of MTsN1 Kediri."

\section{RESEARCH METHOD}

Descriptive quantitative experimental design was chosen as the approach of this research. It means that the result of this research has to be explained descriptively. The data needs to be analyzed by using quantitative because it is related to the formula and number. It was used to calculate the correlation between grammar mastery as variable X1 and vocabulary mastery as variable $\mathrm{X} 2$ toward speaking skill as variable $\mathrm{Y}$.
To get the data population and sample was taken in this research. The population was the seventh grade. There were ten classes of the seventh grade students and whole classes consisted about 376 students. Not all students are taken as sample. The researcher took sample based on Sloven theory.

Finally, after being calculated the sample was 194 students. The sample was taken randomly from whole data gotten. Then, the researcher gave tests and questionnaire to the students. The tests were used for collecting data of grammar and vocabulary mastery. The tests were given to the students in multiple choices consisting 20 questions in each test. The questionaire was used for collecting data of speaking skill. The questionaire was consisting 10 items. This research was conducted in a day. The time of collecting the data was on $19^{\text {th }}$ February 2018.

\section{RESULT AND DISCUSSION}

After getting the data, the researcher calculated it statistically used SPSS software. And these are the results. These results are explained below:

The table follow shows us the descriptive statistic of the data. It contains mean, median, modus, deviation standard, standard error, range, variance, sum, maximum and minimum value. 
https://ejournal.uniska-kediri.ac.id/index.php/PROFICIENCY

Table 1. Descriptive statistic among three variables.

\begin{tabular}{|c|c|c|c|c|}
\hline & & $\begin{array}{l}\text { GRAMMAR } \\
\left(\mathrm{X}_{1}\right)\end{array}$ & $\begin{array}{c}\text { VOCABULARY } \\
\left(\mathrm{X}_{2}\right)\end{array}$ & $\begin{array}{l}\text { SPEAKING } \\
(\mathrm{Y})\end{array}$ \\
\hline \multirow{2}{*}{$\mathrm{N}$} & Valid & 194 & 194 & 194 \\
\hline & Missing & 0 & 0 & 0 \\
\hline \multicolumn{2}{|c|}{ Mean } & 86,96 & 84,28 & 67,41 \\
\hline \multicolumn{2}{|c|}{ Std. Error of Mean } & ,728 & ,844 & ,582 \\
\hline \multicolumn{2}{|c|}{ Median } & 90,00 & 90,00 & 68,00 \\
\hline \multicolumn{2}{|c|}{ Mode } & 95 & 90 & 68 \\
\hline \multicolumn{2}{|c|}{ Std. Deviation } & 10,143 & 11,762 & 8,106 \\
\hline \multicolumn{2}{|c|}{ Variance } & 102,879 & 138,337 & 65,705 \\
\hline \multicolumn{2}{|c|}{ Range } & 35 & 55 & 44 \\
\hline \multicolumn{2}{|c|}{ Minimum } & 65 & 45 & 48 \\
\hline \multicolumn{2}{|c|}{ Maximum } & 100 & 100 & 92 \\
\hline \multicolumn{2}{|c|}{ Sum } & 16870 & 16350 & 13078 \\
\hline
\end{tabular}

From the data above it can be seen that the mean of variable $\mathrm{X} 1$ is $86,96, \mathrm{X} 2$ is 84,28 , and $\mathrm{Y}$ is 67,41 . While median of $\mathrm{X} 1$ is $90, \mathrm{X} 2$ is 90 , and $\mathrm{Y}$ is 68 . Mode of $\mathrm{X} 1$ is $95, \mathrm{X} 2$ is 90, and $\mathrm{Y}$ is 68. Then SDx 1 is $10,143, \mathrm{SDx} 2$ is 11,726 , and SDy is 8,106 . SD.Error $\mathrm{X} 1$ is $0,728, \mathrm{X} 2$ is 0,844 and $\mathrm{Y}$ is 0,582 . The the table shows the minimum and maximum score of variable $\mathrm{X} 1, \mathrm{X} 2$ and $\mathrm{Y}$ namely $65,45 \& 48$ and $100,100 \&$ 92. For the Range of variable $X 1$ is $35, \mathrm{X} 2$ is 55 and $\mathrm{Y}$ is 44 . Then the Variance of variable of $\mathrm{X} 1$ is $102,879, \mathrm{X} 2$ is 138,337 and $\mathrm{Y}$ is 65,705 .

From the frequency most of students have very good grammar mastery.There are 136 students are in very good category and 58 students are in good. Then for the vocabulary master, most of students here have very good vocabulary mastery. There are 130 students are in very good category, 56 students are in good and 8 students are in fair. For the speaking skill, most of students have good speaking skill. There are 10 students are in very good category, 142 students are in good and 42 students are in fair. It can be seen from the diagram as below:

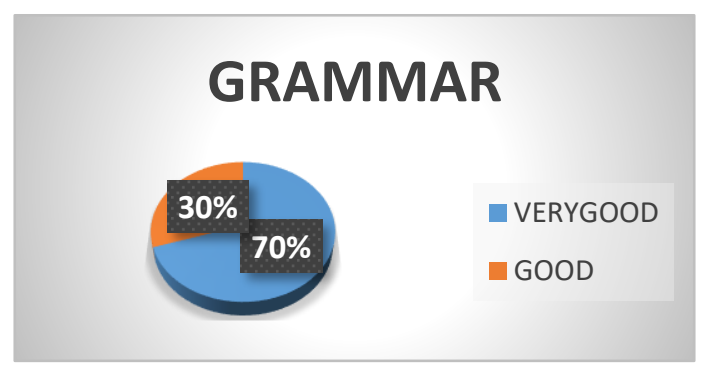
Figure 1 Diagram of Grammar Mastery $\left(\mathbf{X}_{1}\right)$




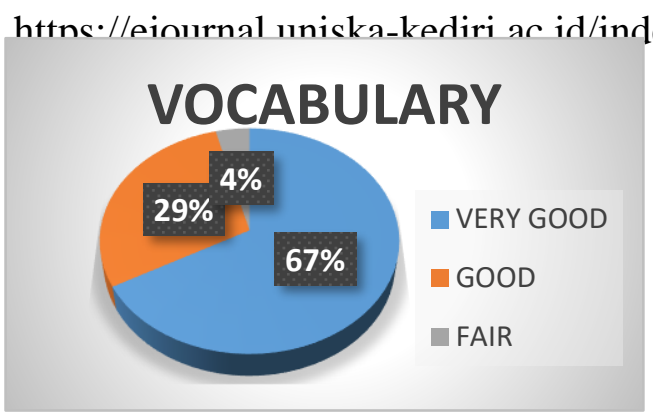

Figure 2 Diagram of Vocabulary Mastery $\left(\mathbf{X}_{2}\right)$

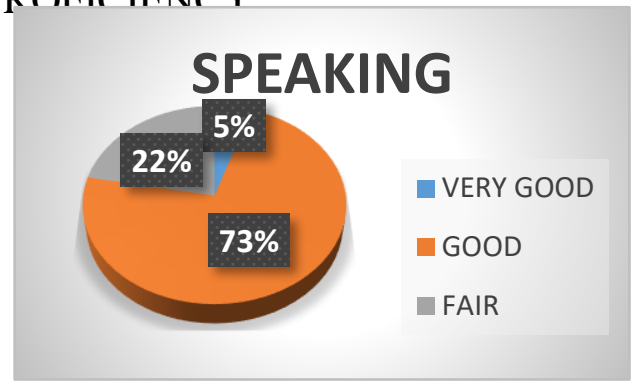

Figure 3 Diagram of Speaking Skill (Y)

The alternative hypohtesis states that there is significant correlation between grammar and vocabulary mastery toward speaking skill among the seventh grade students of MTsN1 Kediri. The result of computation in SPSS is served follow.

Table 2 Correlation Grammar Mastery and Speaking Skill controlled by Vocabulary Mastery

Correlations

\begin{tabular}{|c|c|c|c|c|}
\hline & Control $\mathrm{Vc}$ & iables & GRAMMAR & SPEAKING \\
\hline \multirow{6}{*}{ VOCABULARY } & & Correlation & 1,000 & ,461 \\
\hline & GRAMMAR & Significance (2- tailed) & & 000 \\
\hline & & Df & 0 & 191 \\
\hline & & Correlation & ,461 & 1,000 \\
\hline & SPEAKING & Significance (2-tailed) & ,000 & \\
\hline & & Df & 191 & 0 \\
\hline
\end{tabular}

From the calculation, the correlation between Grammar Mastery $\left(\mathrm{X}_{1}\right)$ and Speaking Skill (Y) controlled by Vocabulary Mastery $\left(\mathrm{X}_{2}\right)$ is 0,461 or $46,1 \%$. So, according to Sugiyono (2011), the correlation between Grammar Mastery $\left(\mathrm{X}_{1}\right)$ and Speaking Skill (Y) controlled by Vocabulary Mastery $\left(\mathrm{X}_{2}\right)$ is in average moderate correlation category because it is in $0,40-0,599$ coefficient correlation. The significance level in 2-tailed is 0,000 , it is less from $5 \%$ or 0,05 . It means there is any partial correlation between Grammar Mastery $\left(\mathrm{X}_{1}\right)$ and Speaking Skill (Y) controlled by Vocabulary Mastery $\left(\mathrm{X}_{2}\right)$. 
https://ejournal.uniska-kediri.ac.id/index.php/PROFICIENCY

Table 3 Correlation between Vocabulary Mastery and Speaking Skill Controlled by Grammar Mastery

\begin{tabular}{|c|c|c|c|c|}
\hline \multicolumn{5}{|c|}{ Correlations } \\
\hline \multicolumn{3}{|c|}{ Control Variables } & VOCABULARY & SPEAKING \\
\hline \multirow{6}{*}{ GRAMMAR } & & Correlation & 1,000 & ,234 \\
\hline & VOCABULARY & Significance (2-tailed) & . & ,001 \\
\hline & & Df & 0 & 191 \\
\hline & \multirow{3}{*}{ SPEAKING } & Correlation & ,234 & 1,000 \\
\hline & & Significance (2-tailed) & 001 & \\
\hline & & Df & 191 & 0 \\
\hline
\end{tabular}

From the calculation, the correlation between Vocabulary Mastery $\left(\mathrm{X}_{2}\right)$ and Speaking Skill (Y) controlled by Grammar Mastery $\left(\mathrm{X}_{1}\right)$ is 0,234 or $23,4 \%$. So, according to Sugiyono (2011), the correlation between Vocabulary Mastery $\left(\mathrm{X}_{2}\right)$ and Speaking Skill (Y) controlled by Grammar Mastery $\left(\mathrm{X}_{1}\right)$ is in correlation category because it is in 0,20-0,399 coefficient correlation. The significance level in 2-tailed is 0,001 , it is less from $5 \%$ or 0,05 . It means there is any partial correlation between Vocabulary Mastery $\left(\mathrm{X}_{2}\right)$ and Speaking Skill (Y) controlled by Grammar Mastery $\left(\mathrm{X}_{1}\right)$.

\section{CONCLUSION AND SUGGESTION}

From explanation in result and disscussion part before, it can be seen that the correlation between $\mathrm{X} 1$
\& $\mathrm{Y}$ is 0,461 and $\mathrm{X} 2$ \& $\mathrm{Y}$ is 0,234 . It means that there is significant correlation between grammar and vocabulary mastery toward speaking skill among the seventh grade students of MTsN1 Kediri. So, the alternative hypothesis is accepted.

For the reader, this research hopefully can be useful for them to give critical support relation with this study because there are many weaknesses under the research. For the teacher, this research hopefully can give knowledge to the teacher to consider that grammar and vocabulary mastery influence students' speaking skill. For the students, this research hopefully can increase their spirit in mastering grammar and vocabulary. For further researchers, this research hopefully can be a reference to conduct the next research. 
https://ejournal.uniska-kediri.ac.id/index.php/PROFICIENCY

\section{REFERENCES}

Arikunto, Suharsimi. (2013). Prosedur Penelitian Suatu Pendekatan Praktik. Jakarta: PT. Rineka Cipta.

Batko, Aan. 2004. When Bad Grammar Happens to Good People: How to Avoid Common Errors in English. Franklin Lakes, NJ: Career Press.

Bisri, M. S. 2015. The Correlation Between Grammar and Vocabulary Mastery Toward Scientific-Writing Ability Among BTP Students of Peace Course Pare Kediri. Kediri: UNISKA.

Bromley, K. (2002). Stretching Students' Vocabulary. New York: Scholastic.

Brown, H. D. 2007. Principles of Language Learning and Teaching. New York: Pearson Education.

Burns, A and Claire, S. 2003. Clearly Speaking: Pronunciation in Action for Teachers. Sydney: Macquaire University.

Kolln, M and Robert F. 2010. Understanding English Grammar: Eight Edition. New York: Pearson.

Larsen, F. D. 2001. Grammar. In Carter R \& Nunan D (eds). The Cambridge Guide to TESOL. Cambridge: CUP.

McCarten, J. (2007). Lesson from The Corprus, Lesson for The Classroom. New York: Cambridge University Press Marketing Department.
Richard-Amato, P. A. 2003. Making It Happen: from Interactive to Participatory Language Teaching: Theory and Practice, $2^{\text {nd }}$ ed. New York: Longman.

Richards and Renandya, E. 2002. Methodology in Language Teaching. London: Cambridge University Press.

Richards, J. C. 2001. Curriculum Development in Language Teaching. Cambridge: Cambridge University Press.

Shumin, K. (2002). Factors to consider: developing adult EFL students' speaking abilities. In J.C. Richard and W.A. Renandya (eds.), Methodology in Language Teaching. Cambridge: Cambridge University Press, 204-211.

Sugiyono. 2011. Metode Penelitian Kuantitatif Kualitatif $R \& D$. Bandung: Alfabeta.

Thornbury, S. 2002. How to Teach Vocabulary. Series Editor: Jeremy Harmer. Malaysia: Longman University of Chicago Press.

Turk, C. 2003. Effective Speaking: Communicating in Speech. London: Spon Press.

Wayan, N. 2013. Improving Speaking Skill Through Cooperative Learning Method of The Eight Grade Students of SMPN 2 Ubud In Academic Year 2012/2013. Denpasar: Universitas Mahasaraswati Denpasar. 